\title{
Profil Kondisi Fisik dan Keterampilan Psikologis Atlet Pencak Silat Perguruan Persinas Asad Kota Bengkulu
}

\section{Profile ff Physical Condition and Psychological Skills ff Athletes Pencak Silat at Persinas Asad College of Bengkulu City}

\author{
Ridho Ismail Aghna Nugraha ${ }^{1}$, Tono Sugihartono ${ }^{2}$, Bogy Restu Illahi ${ }^{3}$ \\ ${ }^{12453}$ Pendidikan Jasmani, Universitas Bengkulu, Jl. WR Supratman Kandang Limun, Bengkulu, \\ 3871A, Indonesia
}

\begin{abstract}
Abstrak
Penelitian ini bertujuan untuk mengetahui Profil Kondisi Fisik dan Keterampilan Psikologis Atlet Pencak Silat Perguruan Persinas ASAD Kota Bengkulu. Jenis penelitian ini adalah penelitian deskriptif kualitatif. Subjek penelitian ini berjumlah 18 orang atlet. Instrumen dan teknik pengumpulan data yang digunakan dalam penelitian ini adalah observasi, kuesioner, tes pengukuran kodisi fisik, dan dokumentasi. Teknik analisis data yang digunakan adalah analisis deskriptif dengan persentase. Pengukuran tes kondisi fisik terdiri dari 1) lari sprint $30 \mathrm{~m}$ untuk mengukur kecepatan, 2) shuttle run untuk mengukur kelincahan, 3) sit and reach untuk mengukur kelentukan, 4) push up dan sit up untuk mengukur kekuatan otot lengan dan perut, 5) multy fitness test untuk mengukur daya tahan. Hasil penelitian menyatakan bahwa persentase hasil kondisi fisik atlet pencak silat Persinas ASAD secara keseluruhan sebesar 55.56\% dengan kategori sedang. Sedangkan instrumen keterampilan psikologis terdiri dari 1) aspek motivasi, 2) aspek percaya diri, 3) aspek kontrol kecemasan, 4) aspek persiapan mental, 5) aspek konsentrasi. Pengumpulan data menggunakan kuesioner The Psychological Skills Inventory for Sports (PSIS). Hasil keterampilan psikologis secara keseluruhan sebesar $61.11 \%$ dengan kategori baik.
\end{abstract}

Kata kunci: Kondisi Fisk, Pencak Silat, Persinas Asad, Psikologi.

\begin{abstract}
The purpose of this research to understand the Profile of Physical Condition and Psychological Skills of Athletes Pencak Silat at Persinas ASAD College of Bengkulu City. This research used descriptive qualitative method. The subject of this research study were 18 athletes. The instruments and data collection techniques used in this study were observation, questionnaires, physical conditional measurement tests, and documentation. The technique analysis data used descriptive analysis with a percentages. Physical condition test measurements consist of 1) $30 \mathrm{~m}$ sprint to measure speed, 2) shuttle run to measure agility, 3) sit and reach to measure flexibility, 4) push ups and sit ups to measure arm and abdominal muscle strength, 5) multy fitness test to measure endurance. The results of the study stated that the percentage of the results of the physical condition of the ASAD athletes pencak silat as a whole was $55.56 \%$ in the moderate category. While the psychological skill instrument consists of 1) motivational aspects, 2) self-confidence aspects, 3) anxiety control aspects, 4) mental preparation aspects, 5) concentration aspects. The data were collected using The Psychological Skills Inventory for Sports (PSIS). The result of psychological skills as a whole is $61.11 \%$ with good categorized.
\end{abstract}

Keywords: Martial arts, Persinas Asad, Physical Condition, Psychological.. 


\section{PENDAHULUAN}

Secara umum olahraga adalah bentuk aktivitas fisik yang terecana dan terstruktur, yang melibatkan gerakan tubuh secara berulang-ulang untuk mendapatkan hasil yang baik. Pada hakikatnya olahraga merupakan suatu proses pendidikan yang memanfaatkan aktivitas jasmani untuk membentuk perubahan secara keseluruhan dalam kualitas individu, baik dalam hal fisik, mental dan emosional.

Kegiatan olahraga meliputi berbagai cabang olahraga seperti atletik, permainan, olahraga air, serta olahraga pencak silat (Ilahi et al, 2020). Selain fungsi olahraga yang meningkatkan kesehatan dan kebugaran jasmani, olahraga juga berfungsi untuk memperoleh prestasi dikejuaraan tingkat provinsi, nasional dan internasional. Setiap cabang olahraga yang bersifat kompetitif, sudah tentu mengharapkan pencapaiannya suatu prestasi puncak. Diantara berbagai olahraga prestasi yang ada, bela diri merupakan salah satu olahraga yang paling cepat berkembang di Indonesia, antara lain Taekwondo (Korea), Karate (Jepang), Tinju (USA), Pencak Silat (Indonesia), Kung Fu (China), dan masih terdapat banyak jenis atau nama bela diri yang masuk dan berkembang di Indonesia.

Salah satu beladiri yang ada di Indonesia yang lebih dikenal dengan pencak silat Persinas ASAD, pencak silat Persinas ASAD tidak hanya diminati oleh orang dewasa, tetapi juga oleh kalangan remaja dan anak-anak, karena keanggotaan Persinas ASAD terbuka untuk umum. Persinas ASAD merupakan perguruan pencak silat asli Indonesia yang berasal dari Jawa Timur dan juga merupakan perguruan yang cukup berprestasi. Prestasi Dunia Persinas ASAD perwakilan dari Indonesia meraih prestasi membanggakan di Festival Beladiri Dunia Chungju World Martial Arts Festival di Chungju Korea Selatan. Persinas ASAD meraih prestasi tiga besar peserta terbaik dengan predikat terbaik bersama peserta dari Jepang dan Cina. Di tingkat Nasional atlet Persinas ASAD juga sering berpartisipasi, terbukti pada tahun 2011, atlet Persinas ASAD pernah menjuarai Sea Games di Indonesia yaitu Erik dan Eka Julianto yang saat ini juga masih aktif di Dunia Persilatan dan sebagai Pelatih Nasional untuk tingkat remaja atau pelajar. 
Ridho Ismail Aghna Nugraha, Tono Sugihartono, Bogy Restu llahi

Profil Kondisi Fisik dan Keterampilan Psikologis Atlet Pencak Silat Perguruan Persinas ASAD Kota Bengkulu

Prestasi olahraga merupakan suatu bentuk kemampuan dan keterampilan seorang atlet dalam menyelesaikan tugas-tugas baik dalam kompetisi beregu maupun individu untuk mencapai hasil yang optimal. Menurut (Fauji, 2020) bahwa ada tiga faktor yang mempengaruhi pencapaian prestasi yang optimal yaitu faktor fisik, faktor teknik dan faktor psikologis. Fisik merupakan segala sesuatu yang berkaitan dengan tubuh. Teknik merupakan gerakan-gerakan yang digunakan dalam cabang olahraga pencak silat. Sedangkan psikologi merupakan salah satu pembentukan mental atlet silat dalam menghadapi suatu pertandingan atau menghadapi lawan.

Kondisi fisik merupakan satu kesatuan dari komponen kondisi fisik yang saling berhubungan. Komponen fisik yang dibutuhkan dalam pencak silat diantaranya kecepatan, kelentukan, kekuatan, dan daya tahan, Hariono dalam (Fauji, 2020). Seorang atlet dapat dikatakan dalam keadaan kondisi fisik yang prima kalau atlet mampu melakukan aktivitas yang dibebankan kepadanya atau yang dilakukannya tanpa kelelahan yang berlebihan (Agustin \& Sulistyarto, 2017).

Psikologis olahraga juga memiliki peran penting dalam peningkatan prestasi olahraga. (Weinberg \& Gould, 2011) dalam penelitiannya mengungkapkan keberhasilan dan kegagalan pemain dalam olahraga prestasi sangat ditentukan oleh perpaduan dari kemampuan faktor fisik dan psikologis bahkan untuk cabang olahraga tertentu faktor psikologis tersebut mencapai $80 \%$ sampai 90\%. Begitu juga menurut Lutan dalam (Dongoran et al., 2019) atlet harus memiliki keterampilan psikologis dan moral yang dibutuhkan oleh olahraga yang ditekuninya untuk berprestasi.

Menurut (Nopiyanto et al., 2021) dalam penelitiannya menyatakan bahwa faktor psikologis yang utama dan penting pada pencapaian prestasi terbaik atlet terdiri dari motivasi, percaya diri, kontrol kecemasan, persiapan mental, dan konsentasi. Dikarenakan pentingnya kondisi fisik dan keterampilan psikologis pada cabang olahraga pencak silat, maka perlu dilakukan penelitian yang lebih mendalam tentang profil kondisi fisik dan keterampilan psikologis atlet pencak silat. Berdasarkan apa yang telah dikemukakan diatas maka peneliti tertarik untuk 
Ridho Ismail Aghna Nugraha, Tono Sugihartono, Bogy Restu llahi

Profil Kondisi Fisik dan Keterampilan Psikologis Atlet Pencak Silat Perguruan Persinas ASAD Kota Bengkulu

meneliti masalah tersebut dengan judul "Profil Kondisi Fisik dan Keterampilan Psikologis Atlet Pencak Persinas ASAD Kota Bengkulu”.

\section{METODE}

Berdasarkan permasalahan dan tujuan penelitian yang telah dibahasa sebelumnya, maka metode yang digunakan dalam penelitian yang berjudul Profil Kondisi Fisik dan Keterampilan Psikologis Atlet Pencak Silat Perguruan Persinas ASAD Kota Bengkulu yaitu metode deskriptif kualitatif. Menurut (Ra'co, 2018) penelitian deskriptif yaitu metode yang digunakan peneliti untuk melakukan penelitian suatu objek, suatu sistem pemikiran, peristiwa yang dialami sekarang atau status kelompok manusia. Penelitian deskriptif ini bertujuan untuk menggambarkan secara sistematis dan akurat mengenai fakta-fakta, hubungan atau sifat-sifat antara fenomena yang diselidiki. Tempat dan waktu penelitian ini dilaksanakan di lapangan latihan perguruan Persinas ASAD Kota Bengkulu dari tanggal 15 April - 10 Mei 2021. Subjek yang digunakan dalam penelitian ini adalah 18 atlet pencak silat Persinas ASAD di Kota Bengkulu.

Tabel 1. Subjek Penelitian

\begin{tabular}{cc}
\hline Tempat latihan Perguruan Persinas ASAD Kota Bengkulu & Jumlah Atlet \\
\hline Padang Kemiling & 10 \\
Kebun Tebeng & 8 \\
\hline Total & 18 \\
\hline
\end{tabular}

Teknik pengumpulan data dalam penelitian ini menggunakan observasi, tes pengukuran, kuesioner dengan angket tertutup dan dokumentasi (Sugiyono, 2019). Keterampilan psikologis atlet dikumpulkan dengan menggunakan kuesioner The Psychological Skills Inventory for Sports (PSIS) yang diadopsi dari Mahoney, Gabriel \& Perkins, 1987 dalam (Nopiyanto \& Dimyati, 2018). Teknik analisis data menggunakan Aktivitas dalam analisis data, yaitu reduction data, display data, dan conclusion darwing/veryfication. Selanjutnya dapat dilakukan pemaknaan sebagai pembahasan atas permasalahan yang diajukan dalam bentuk persentase. Dengan rumus yang digunakan (Sudijono, 2011).

$$
P=f / n \times 100 \%
$$




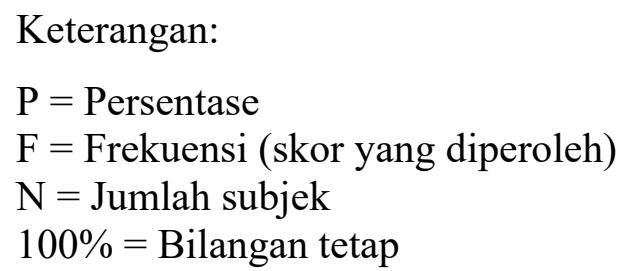

\section{HASIL}

Penelitian ini dilakukan di lapangan latihan perguruan Persinas ASAD Kota Bengkulu dengan teknik pengumpulan data menggunakan observasi, tes dan pengukuran, kuesioner, serta dokumentasi yang diperoleh dari para atlet pencak silat Persinas ASAD Kota Bengkulu. Berikut merupakan hasil penelitian yang telah dilaksanakan:

\section{Hasil Kondisi Fisik}

Tabel 2. Hasil Kondisi Fisik Atlet Pencak Silat Perguruan Persinas ASAD Kota Bengkulu Secara Keseluruhan

\begin{tabular}{ccccc}
\hline No & Skor & Kategori & Frekuensi & Persentase \\
\hline 1. & $25,2-30$ & Sangat Baik & 1 & $5,56 \%$ \\
2. & $20,5-25,2$ & Baik & 6 & $33,33 \%$ \\
3. & $15,6-20,4$ & Cukup & 10 & $55,56 \%$ \\
4. & $10,8-15,5$ & Kurang & 1 & $5,56 \%$ \\
5. & $<6$ & Sangat Kurang & & $100 \%$ \\
\hline \multicolumn{7}{r}{ Jumlah } & 18 & \\
\hline
\end{tabular}

Berdasarkan tabel 2 hasil di atas diketahui kondisi fisik atlet pencak silat Persinas ASAD Kota Bengkulu secara keseluruhan 1 atlet masuk dikategori sangat baik, 6 atlet masuk kategori baik, 10 atlet masuk kategori cukup, dan 1 atlet masuk kategori kurang.

Gambar 1. Diagram Persentase Kondisi Fisik Atlet Pencak Silat Persinas ASAD Kota Bengkulu Secara Keseluruhan

Berdasarkan Gambar 1 dapat disimpulkan bahwa atlet yang memiliki kondisi fisik sangat baik dengan persentase 5,56\%, atlet yang memiliki kondisi fisik baik dengan persentase 33,33\%, atlet yang memiliki kondisi fisik cukup dengan persentase 55,56\%, atlet yang memiliki kondisi fisik kurang dengan 
Ridho Ismail Aghna Nugraha, Tono Sugihartono, Bogy Restu llahi

Profil Kondisi Fisik dan Keterampilan Psikologis Atlet Pencak Silat Perguruan Persinas ASAD Kota Bengkulu

persentase 5,56\%, dan untuk kondisi fisik sangat kurang dengan persentase $0 \%$.

Sehingga dapat disimpulkan bahwa kondisi fisik secara keseluruhan atlet pencak silat Persinas ASAD Kota Bengkulu dengan kategori sedang.

Berdasarkan data hasil tes pada tabel 3 di atas, maka hasil analisis deskripsi data profil kondisi fisik atlet pencak silat Persinas ASAD Kota Bengkulu menunjukan gambaran komponen kondisi fisik yang terdiri dari unsur:

Tabel 3. Data Hasil Kecepatan Lari Sprint 30 meter Atlet Pencak Silat Persinas ASAD Kota Bengkulu

\begin{tabular}{rcccc}
\hline No & Skor & Kategori & Frekuensi & Persentase (\%) \\
\hline 1 & $<4,59$ & Sangat Baik & 3 & 16,67 \\
2 & $4,60-5,09$ & Baik & 4 & 22,22 \\
3 & $5,10-5.29$ & Sedang & 8 & 44,44 \\
4 & $5,30-5.59$ & Kurang & 3 & 16,67 \\
5 & $>5,60$ & Sangat Kurang & & \\
\hline \multicolumn{7}{r}{ Jumlah } & & $\mathbf{1 8}$ & $\mathbf{1 0 0}$ \\
\hline
\end{tabular}

Tabel 4. Data Hasil Kelincahan Shuttle Run Atlet Pencak Silat Persinas ASAD Kota Bengkulu

\begin{tabular}{rcccc}
\hline No & Skor & Kategori & Frekuensi & Persentase (\%) \\
\hline 1 & $>12,1$ & Sangat Baik & 2 & 11,11 \\
2 & $12,11-13,53$ & Baik & 4 & 22,22 \\
3 & $13,54-14,96$ & Cukup & 9 & 50,00 \\
4 & $14,98-16,39$ & Kurang & 3 & 16,67 \\
5 & $<16,4$ & Sangat Kurang & & \\
\hline \multicolumn{2}{r}{ Total } & & $\mathbf{1 8}$ & $\mathbf{1 0 0}$ \\
\hline
\end{tabular}

Tabel 5. Data Hasil Kelentukan Sit and Reach Atlet Pencak Silat Persinas ASAD Kota Bengkulu

\begin{tabular}{rcccc}
\hline No & Skor & Kategori & Frekuensi & Persentase (\%) \\
\hline 1 & $>44,45$ & Sangat Baik & 1 & 5,56 \\
2 & $38,1-44,44$ & Baik & 6 & 33,33 \\
3 & $33,01-37,9$ & Cukup & 8 & 44,44 \\
4 & $25,5-33,02$ & Kurang & 3 & 16,67 \\
5 & $<25,4$ & Sangat Kurang & & \\
\hline \multicolumn{7}{r}{ Total } & & $\mathbf{1 8}$ & $\mathbf{1 0 0}$ \\
\hline
\end{tabular}

Tabel 6. Data Hasil Kekuatan Otot Lengan Atlet Pencak Silat Persinas ASAD Kota Bengkulu

\begin{tabular}{rcccc}
\hline No & Skor & Kategori & Frekuensi & Persentase (\%) \\
\hline 1 & $>56$ & Sangat Baik & 1 & 5,56 \\
2 & $47-55$ & Baik & 3 & 16,67 \\
3 & $35-46$ & Cukup & 10 & 55,56 \\
4 & $19-34$ & Kurang & 4 & 22,22 \\
5 & $<18$ & Sangat Kurang & & $\mathbf{1 0 0}$ \\
\hline
\end{tabular}


Ridho Ismail Aghna Nugraha, Tono Sugihartono, Bogy Restu llahi

Profil Kondisi Fisik dan Keterampilan Psikologis Atlet Pencak Silat Perguruan Persinas ASAD Kota Bengkulu

Tabel 7. Data Hasil Kekuatan Otot Perut Atlet Pencak Silat Persinas ASAD Kota Bengkulu

\begin{tabular}{rcccc}
\hline No & Skor & Kategori & Frekuensi & Persentase (\%) \\
\hline 1 & $>70$ & Sangat Baik & 2 & 11,11 \\
2 & $54-69$ & Baik & 7 & 38,89 \\
3 & $38-53$ & Cukup & 8 & 44,44 \\
4 & $22-37$ & Kurang & 1 & 5,56 \\
5 & $<21$ & Sangat Kurang & & $\mathbf{1 0 0}$ \\
\hline
\end{tabular}

Tabel 8. Data Hasil Multy Fitness Test Atlet Pencak Silat Persinas ASAD Kota Bengkulu

\begin{tabular}{rcccc}
\hline No & Skor & Kategori & Frekuensi & Persentase (\%) \\
\hline 1 & $46,5-52,4$ & Sangat Baik & 2 & 11,11 \\
2 & $42,5-46,4$ & Baik & 5 & 27,78 \\
3 & $36,5-42,4$ & Cukup & 9 & 50,00 \\
4 & $33,0-36,4$ & Kurang & 1 & 5,56 \\
5 & $<33$ & Sangat Kurang & 1 & 5,56 \\
\hline & Total & & $\mathbf{1 8}$ & $\mathbf{1 0 0}$ \\
\hline
\end{tabular}

\section{Hasil Kuesioner}

Tabel 9. Hasil Kuesioner Keterampilan Psikologis Atlet Pencak Silat Persinas ASAD Kota Bengkulu Secara Keseluruhan

\begin{tabular}{ccccc}
\hline No & Skor & Kategori & Frekuensi & Persentase (\%) \\
\hline 1. & $>138,6$ s.d 165 & Sangat Baik & 5 & 27,78 \\
2. & $>112,2$ s.d 138,5 & Baik & 11 & 61,11 \\
3. & $>85,8$ s.d 112,1 & Cukup & 2 & 11,11 \\
4. & $>59,4$ s.d 85,7 & Kurang & & \\
5. & $<33$ s.d 59,3 & Sangat Kurang & & \\
\hline & Jumlah & & $\mathbf{1 8}$ & $\mathbf{1 0 0}$ \\
\hline
\end{tabular}

Berdasarkan tabel 3 hasil kuesioner di atas diketahui Keterampilan

Psikologis Atlet Pencak Silat Persinas ASAD Kota Bengkulu sangat baik berjumlah hanya 5 orang atlet, hasil baik jumlah 11 orang atlet, sedangkan hasil cukup jumlah 2 orang atlet.

Gambar 2. Diagram Persentase Kuesioner Keterampilan Psikologis Atlet Pencak Silat Persinas ASAD Kota Bengkulu Secara Keseluruhan

Berdasarkan gambar 2 dapat disimpulkan bahwa atlet yang memiliki keterampilan psikologis sangat baik dengan persentase $27,78 \%$, atlet yang memiliki keterampilan psikologis baik dengan persentase $61,11 \%$, atlet yang memiliki keterampilan psikologis cukup dengan persentase $11,11 \%$, sedangkan 
Ridho Ismail Aghna Nugraha, Tono Sugihartono, Bogy Restu llahi

Profil Kondisi Fisik dan Keterampilan Psikologis Atlet Pencak Silat Perguruan Persinas ASAD Kota Bengkulu

untuk keterampilan psikologis kurang serta sangat kurang $0 \%$. Sehingga dapat disimpulkan bahwa keterampilan psikologis atlet pencak silat Persinas ASAD Kota Bengkulu dengan kategori Baik.

Tabel 10. Hasil Kuesioner Keterampilan Psikologis Atlet Pencak Silat Perguruan Persinas ASAD Kota Bengkulu Aspek Motivasi

\begin{tabular}{cccccc}
\hline No & \multicolumn{2}{c}{ Skor } & Kategori & Frekuensi & Persentase (\%) \\
\hline 1. & $>33$ & s.d. 40 & Sangat Baik & 10 & 55,56 \\
2. & $>27$ s.d. 32 & Baik & 7 & 38,89 \\
3. & $>21$ s.d. 26 & Cukup & 1 & 5,56 \\
4. & $>14$ & s.d. 20 & Kurang & & \\
5. & 8 & s.d. 13 & Sangat Kurang & & $\mathbf{1 0 0}$ \\
\hline \multicolumn{7}{r}{} \\
\hline
\end{tabular}

Tabel 11. Hasil Kuesioner Keterampilan Psikologis Atlet Pencak Silat Perguruan Persinas ASAD Kota Bengkulu Aspek Percaya Diri

\begin{tabular}{|c|c|c|c|c|}
\hline No & Skor & Kategori & Frekuensi & Persentase (\%) \\
\hline 1 & 29 s.d 35 & Sangat Baik & 4 & 22,22 \\
\hline 2 & 23 s.d 28 & Baik & 12 & 66,67 \\
\hline 3 & 18 s.d 22 & Cukup & 2 & 11,11 \\
\hline 4 & 13 s.d 17 & Kurang & & \\
\hline 5 & 7 s.d 12 & Sangat Kurang & & \\
\hline \multicolumn{3}{|c|}{ Jumlah } & 18 & 100 \\
\hline
\end{tabular}

Tabel 12. Hasil Kuesioner Keterampilan Psikologis Atlet Pencak Silat Perguruan Persinas ASAD Kota Bengkulu Aspek Kontrol Kecemasan

\begin{tabular}{|c|c|c|c|c|}
\hline No & Skor & Kategori & Frekuensi & Persentase (\%) \\
\hline 1 & 29 s.d 35 & Sangat Baik & 6 & 33,33 \\
\hline 2 & 23 s.d 28 & Baik & 9 & 50,00 \\
\hline 3 & 18 s.d 22 & Cukup & 3 & 16,67 \\
\hline 4 & 13 s.d 17 & Kurang & & \\
\hline 5 & 7 s.d 12 & Sangat Kurang & & \\
\hline \multicolumn{3}{|c|}{ Jumlah } & 18 & 100 \\
\hline
\end{tabular}

Tabel 13. Hasil Kuesioner Keterampilan Psikologis Atlet Pencak Silat Perguruan Persinas ASAD Kota Bengkulu Aspek Persiapan Mental

\begin{tabular}{ccccc}
\hline No & Skor & Kategori & Frekuensi & Persentase (\%) \\
\hline 1 & 21 s.d 25 & Sangat Baik & 1 & 5,56 \\
2 & 17 s.d 20 & Baik & 12 & 66,67 \\
3 & 13 s.d 16 & Cukup & 5 & 27,78 \\
4 & 9 s.d 12 & Kurang & & \\
5 & 5 s.d 8 & Sangat Kurang & $\mathbf{1 8}$ & $\mathbf{1 0 0}$ \\
\hline \multicolumn{5}{r}{} \\
\hline
\end{tabular}

Tabel 14. Hasil Kuesioner Keterampilan Psikologis Atlet Pencak Silat Perguruan Persinas ASAD Kota Bengkulu Aspek Konsentrasi

\begin{tabular}{|c|c|c|c|c|}
\hline No & Skor & Kategori & Frekuensi & Persentase (\%) \\
\hline 1 & 25 s.d 30 & Sangat Baik & 7 & 38,89 \\
\hline 2 & 20 s.d 24 & Baik & 10 & 55,56 \\
\hline 3 & 16 s.d 19 & Cukup & 1 & 5,56 \\
\hline 4 & 11 s.d 15 & Kurang & & \\
\hline 5 & 6 s.d 10 & Sangat Kurang & & \\
\hline \multicolumn{3}{|c|}{ Jumlah } & 18 & 100 \\
\hline
\end{tabular}


Ridho Ismail Aghna Nugraha, Tono Sugihartono, Bogy Restu llahi

Profil Kondisi Fisik dan Keterampilan Psikologis Atlet Pencak Silat Perguruan Persinas ASAD Kota Bengkulu

\section{Hasil Dokumentasi}

Dokumentasi diperoleh dari sertifikat/piagam atlet dan proses latihan atlet pencak silat perguruan Persinas ASAD Kota Bengkulu.

\section{PEMBAHASAN}

Analisis merupakan proses mengungkapkan sesuatu secara ilmiah berdasarkan kajian tertentu. Dalam penelitian ini, data akan dibahas berdasarkan hasil observasi, hasil tes dan pengukuran, hasil kuesioner serta hasil dokumentasi profil kondisi fisik dan keterampilan psikoogis atlet pencak silat perguruan Persinas ASAD Kota bengkulu. Berikut merupakan pembahasan dari penelitian yang telah dilakukan

\section{Observasi Atlet Pencak Silat Persinas ASAD Kota Bengkulu}

Berdasarkan hasil observasi yang telah dilakukan, bahwasannya atlet pencak silat Persinas ASAD Kota Bengkulu memiliki 2 orang pelatih yang bernama Triono dan Sarjono dengan jumlah atlet sebanyak 18 orang. Jadwal latihan atlet pencak silat perguruan Persinas ASAD Kota Bengkulu dilaksanakan satu minggu tiga kali yaitu dihari selasa, kamis, dan minggu. Proses latihan atlet dilakukan di lapangan latihan pencak silat Persinas ASAD yang berpusat di J1 Merapi No. 12, Kebun Tebeng, Kec. Ratu Agung.

Observasi yang dilakukan oleh peneliti dalam penelitian ini adalah mengikuti observasi secara pasif. Peneliti melihat secara langsung kegiatan latihan atlet perguruan Persinas ASAD karena peneliti tinggal di asrama tempat latihan perguruan Persinas ASAD Kota Bengkulu. Selama observasi berlangsung, hasil pengamatan kegiatan sebagai berikut: a) peneliti melihat pelaksanaan latihan pada perguruan Persinas ASAD Kota Bengkulu sudah terlaksana dengan baik, b) pelatih di perguruan Persinas ASAD Kota Bengkulu melatih atletnya dengan penuh semangat dan mempunyai target tersendiri untuk atlet yang dilatih, c) struktur organisasi perguruan Persinas ASAD Kota Bengkulu sudah berjalan dengan baik, d) sarana dan prasarana perguruan Persinas ASAD Kota Bengkulu sudah memadai untuk menunjang latiahan maupun bertanding atlet.

Para atlet juga memiliki kedisiplinan yang baik hal itu dibuktikan dengan selalu datang tepat waktu saat jam latihan serta selalu mengikuti program latihan dengan baik dan maksimal. Tidak ada keluhan yang dirasakan atlet saat 
Ridho Ismail Aghna Nugraha, Tono Sugihartono, Bogy Restu llahi

Profil Kondisi Fisik dan Keterampilan Psikologis Atlet Pencak Silat Perguruan Persinas ASAD Kota Bengkulu

melakukan sesi latihan, semua program latihan yang diberikan oleh pelatih mereka laukan dengan baik serta dengan penuh semangat.

\section{Kondisi Fisik Atlet Pencak Silat Persinas ASAD Kota Bengkulu}

Hasil dari penelitian ini menunjukkan bahwa kondisi fisik atlet pencak silat perguruan Persinas ASAD Kota Bengkulu secara keseluruhan masuk dalam kategori sedang dengan persentase 55,56\%. Kondisi fisik dapat diukur dengan parameter tes dan pengukuran kondisi fisik yang terdiri dari 1) sprint $30 \mathrm{~m}$ untuk mengukur kecepatan, 2) shuttle run untuk mengukur kelincahan, 3) sit and reach untuk mengukur kelentukan 4) push ups dan sit ups untuk mengukur kekuatan otot lengan dan perut, dan 5) bleep test untuk mengukur daya tahan (Prabowo et al., 2020)

Secara khusus, kondisi fisik atlet pencak silat perguruan Persinas ASAD Kota Bengkulu pada tes sit and reach dikategorikan sedang dengan persentase sebesar 44,44\%. Dari lari 30 meter, tes ini bertujuan untuk mengetahui kecepatan atlet pencak silat yang dikategorikan sedang dengan persentase sebesar $44,44 \%$. Hasil tes shuttle run $3 \mathrm{~m}$ x 5 bertujuan untuk mengetahui kelincahan atlet pencak silat dikategorikan sedang dengan persentase 50,00\%. Hasil tes push up 1 menit bertujuan untuk mengetahui kekuatan dikategorikan sedang dengan persentase $55,56 \%$. Hasil tes sit up 2 menit bertujuan untuk mengetahui kekuatan dikategorikan sedang dengan persentase $44,44 \%$. Hasil pengukuran multy level test bertujuan untuk mengetahui daya tahan dikategorikan sedang dengan persentase 50,00\%. Secara keseluruhan hasil kondisi fisik atlet pencak silat Persinas ASAD Kota Bengkulu dikategorikan sedang dengan persentase 55,56\%.

\section{Keterampilan Psikologis Atlet Pencak Silat Persinas ASAD Kota Bengkulu}

Keterampilan psikologis adalah kemampuan untuk atlet untuk mengatasi tantangan untuk mencapai prestasi terbaik (Sugihartono et al., 2021). Hasil kuesioner keterampilan psikologis secara keseluruhan atlet pencak silat Persinas ASAD Kota Bengkulu masuk dalam kategori baik dengan persentase 61,11\%. Secara khusus, keterampilan psikologi atlet pencak silat perguruan Persinas ASAD Kota Bengkulu pada aspek motivasi dikategorikan sangat baik dengan persentase sebesar 55,56\%. Hasil penelitian ini juga didukung oleh hasil penelitian sebelumnya yang menyatakan bahwa motivasi yang tinggi sangat 
dibutuhkan oleh atlet dan tidak dapat dipisahkan dari atlet untuk menapai kesuksesan (Nopiyanto \& Dimyati, 2018). Untuk menjadi atlet yang sukses maka diperlukan motivasi yang sangat tinggi (Triananda et al., 2021), bahkan motivasi tidak dapat dipisahkan dari cabang olahraga individu karena untuk mencapai kesuksesan dipertandingan atlet pencak silat Persinas ASAD membutuhkan motivasi yang tinggi.

Dari aspek percaya diri, keterampilan psikologi atlet pencak silat perguruan Persinas ASAD Kota Bengkulu dikategorikan baik dengan persentase $66,67 \%$. Atlet yang memiliki rasa percaya diri tidak akan ragu dengan kemampuan yang dimiliki atlet tersebut. (Komarudin, 2014) menjelaskan bahwa atlet yang memiliki kepercayaan diri selalu berpikir positif untuk menampilankan sesuatu yang terbaik dan memungkinkan timbul keyakinan pada dirinya bahwa dirinya mampu melakukannya sehingga penampilannya tetap baik. Kepercayaan diri sangat penting dalam cabang olahraga beladiri pencak silat karena membuat keyakinan untuk berhasil yang mengubah penilaian negatif menjadi positif. Oleh karena itu salah satu modal utama dan syarat mutlak untuk mencapai prestasi olahraga beladiri pencak silat yang gemilang adalah memiliki percaya diri. Hal ini terbukti dari hasil penelitian diketahui atlet pencak silat Persinas ASAD memiliki keterampilan psikologi aspek percaya diri dalam kategori baik.

Dari aspek pengendalian kecemasan, Keterampilan Psikologi Atlet Pencak Silat Perguruan Persinas ASAD Kota Bengkulu dikategorikan baik dengan persentase $50,00 \%$. Kecemasan adalah salah satu gejala psikologis yang berkaitan dengan perasaan negatif pada seseorang. Sejalan dengan pendapat (Jatra \& Raibowo, 2021) kecemasan adalah perasaan negatif yang ditandai dengan ketegangan, kekhawatiran, ketakutan tentang apa yang akan terjadi dan peristiwa yang berkaitan dengan aktivitas gairah. Kecemasan yang terjadi pada atlet pencak silat berpengaruh terhadap penampilannya. Penampilan puncak pada dasarnya bisa dialami oleh setiap atlet pencak silat ketika atlet tersebut dapat menyeimbangkan antara pikiran dan fisik. Kecemasan yang terjadi pada atlet biasanya akan menganggu penampilannya dan atlet tersebut mempunyai perasaan takut jika gagal dalam pertandingan serta menimbulkan adanya beban moral jika tidak bisa memenangkan pertandingan tersebut (Raibowo et al., 2021). Hal itulah 
yang mendasari pentingnya pengendalian terhadap kecemasan dalam olahraga pencak silat agar atlet mampu menguasai perasaan cemas yang dirasakan yang dapat berpengaruh negatif terhadap penampilan atlet. Berdasarkan hasil penelitian diketahui atlet pencak silat Persinas ASAD memiliki keterampilan psikologi aspek pengendalian kecemasan dalam kategori baik.

Dari aspek persiapan mental, Keterampilan Psikologi Atlet Pencak Silat Perguruan Persinas ASAD Kota Bengkulu dikategorikan baik dengan persentase $66,67 \%$. Hal ini dibuktikan atlet memiliki persiapan mental yang baik sebagai strategi untuk mendorong, mengontrol dan memerintah melakukan aktivitas motorik yang dapat mengatasi gangguan seperti kecemasan yang dapat mempengaruhi pada peningkatan peforma atlet dalam pertandingan. Sehingga atlet yang memiliki mental baik diharapkan dapat meraih prestasi yang maksimal. Aspek penting yang dapat menentukan keberhasilan atlet di arena pertandingan, salah satunya adalah ketangguhan mental (Omar-Fauzee et al., 2012). Berdasarkan hasil penelitian diketahui atlet pencak silat Persinas ASAD memiliki keterampilan aspek psikologi persiapan mental dalam kategori baik.

Dari aspek konsentrasi, Keterampilan Psikologi Atlet Pencak Silat Perguruan Persinas ASAD Kota Bengkulu dikategorikan baik dengan persentase $55,56 \%$. Konsentrasi merupakan salah satu faktor psikologis yang berpengaruh terhadap penampilan atlet. Konsentrasi memainkan peran yang sangat penting dalam pertunjukan, jika terganggu itu akan menimbulkan masalah (Raibowo et al., 2021). Konsentrasi ialah kemampuan untuk mempertahankan fokus terhadap kegiatan-kegiatan yang ada di dalam suatu lingkungan atau suasana ketika lingkungan berubah secara cepat pada pikiran tentang masa lalu atau masa depan yang menyebabkan isyarat-isyarat yang tidak bersangkut paut sering membuat penampilan kacau (Apta et al., 2014). Hal ini dibuktikan atlet mampu berkonsentrasi untuk memusatkan perhatian pada tugas dengan tidak terganggu dan terpengaruh dari stimulus yang bersifat internal dan eksternal sehingga atlet dapat melakukan penampilan yang tepat. Berdasarkan hasil penelitian diketahui atlet pencak silat Persinas ASAD memiliki keterampilan aspek psikologi konsentrasi dalam kategori baik. 
Ridho Ismail Aghna Nugraha, Tono Sugihartono, Bogy Restu llahi

Profil Kondisi Fisik dan Keterampilan Psikologis Atlet Pencak Silat Perguruan Persinas ASAD Kota Bengkulu

\section{KESIMPULAN}

Berdasarkan hasil penelitian yang telah diperoleh, bahwa hasil penelitian menyatakan persentase hasil kondisi fisik atlet pencak silat Persinas ASAD secara keseluruhan sebesar 55,56\% dengan kategori sedang. Sedangkan hasil keterampilan psikologis secara keseluruhan sebesar 61,11\% dengan kategori baik.

\section{REFERENSI}

Agustin, D., \& Sulistyarto, S. (2017). Analisis Kondisi Fisik Atlet Putri Floorball Universitas Negeri Surabaya. 05 (02), 29-36.

Apta, B., Harrison, M. J., Bénézech, C., Karim, S., Ware, C. F., Lalor, P. F., Caamaño, J. H., \& Rainger, G. E. (2014). Lymphotoxin- $\beta$ receptor signalling links steatohepatitis, hyper-lipidemia and atherosclerosis. Atherosclerosis, 232(2), e4.

Dongoran, Nopiyanto, Y., Saputro, D., \& Nugroho, A. (2019). Comparison of Psychological Skills of Pencak Silat and Boxing Athletes (Study on Indonesian Training Camp athletes). 383(Icss), 124-128. https://doi.org/10.2991/icss-19.2019.210

Fauji, R. O. (2020). Usia 12-15 Tahun Di Kolat Klipang Kota Semarang Tahun 2019.

Ilahi, B. R., Syafrial, \& Hiasa, F. (2020). Implementasi Model Pembelajaran Kooperatif Tipe Numbered Heads Together pada Mahasiswa Pendidikan Jasmani Universitas Bengkulu. Halaman Olahraga Nusantara (Jurnal Ilmu Keolahragaan), 3(2), 207-213. https://doi.org/10.31851/hon.v3i2.4858

Jatra, R., \& Raibowo, S. (2021). Anxiety and Concentration of Tennis Athlete. Kinestetik: Jurnal Ilmiah Pendidikan Jasmani, 5(3), 580-589. https://doi.org/10.33369/jk.v5i3.17500

Komarudin. (2014). Psikologi Olahraga. PT Remaja Rosdakarya.

Nopiyanto, Y. E., \& Dimyati, D. (2018). Karakteristik psikologis atlet Sea Games Indonesia ditinjau dari jenis cabang olahraga dan jenis kelamin. Jurnal Keolahragaan, 6(1), 69-76.

Nopiyanto, Y. E., Raibowo, S., \& Prabowo, G. U. (2021). Psychological Characteristics of Athletes at Pusat Pendidikan dan Latihan Pelajar ( PPLP ) in Bengkulu. Journal Sport Area, 6(1), 37-43. https://doi.org/doi.org/10.25299/sportarea.2021.vol6(1).5572

Omar-Fauzee, M. S., Saputra, Y. H., Samad, N., Gheimi, Z., Asmuni, M. N., \& Johar, M. (2012). Mental toughness among footballers: A case study. International Journal of Academic Research in Business and Social Sciences, $2(1), 639$.

Prabowo, A., Ihsan, N., Barlian, E., \& Welis, W. (2020). Development of digital based vertical jump test instruments. Journal of Physics: Conference Series, 1481(1), 1-7. https://doi.org/10.1088/1742-6596/1481/1/012029

Raibowo, S., Jatra, R., Prabowo, A., Nopiyanto, Y. E., \& Ilahi, B. R. (2021). Anxiety and Concentration of Tennis Chair Umpire. Halaman Olahraga Nusantara (Jurnal Ilmu Keolahragaan), 4(Ii), 271-281. https://doi.org/10.31851/hon.v4i25640 
Sudijono, A. (2011). Pengantar Statistik Pendidikan. In Anas Sudijono. Raja Grapindo Persada.

Sugihartono, T., Nopiyanto, Y. E., \& Raibowo, S. (2021). The relationship between athletes' perceptions of Covid-19 and communication with the psychological skills. Journal Sport Area, 6(2), 183-192.

Sugiyono. (2019). Metode Penelitian Kuantitatif, Kualitatif, dan R\&D (2(1)). Alfabetha.

Triananda, A., Syafrial, \& Nopiyanto, Y. E. (2021). Karakteristik Psikologis Atlet PON Bengkulu Ditinjau dari Cabang Olahraga Individu. Sport Gymnastics: Jurnal Ilmiah Pendidikan Jasmani, 2(1), 126-137. https://doi.org/10.33369/gymnastics

Weinberg, R. S., \& Gould, D. (2011). Foundations of Sport and Exercise Psychology. Human Kinetics. 